Click www.researchjournal.co.in/online/subdetail.html to purchase.

A REVIEW

International Journal of Agricultural Engineering | Volume 13 | Issue 2 | October, 2020 | 267-271

$\Rightarrow$ ISSN-0974-2662 $\square$ Visit us : www.researchjournal.co.in D DOI: 10.15740/HAS/IJAE/13.2/267-271

\title{
Reusing waste materials in concrete
}

\section{Rohit Kumar and Ritesh Jain}

Received : 03.07.2020; Accepted : 26.09.2020

See end of the Paper for authors' affiliation

Correspondence to :

Rohit Kumar

Bachelor of Agricultural

Engineering, Punjab

Agricultural University,

Ludhiana (Punjab) India

Email:rohit-1702385@pau.edu
- ABSTRACT : Studies on glass powder (GP) and plastic incorporation in concrete and characteristics exhibited by mixtures prepared using different percentages have been carried out in the past and this review summarises the studies carried out in the past decade and presents the current understanding in the area. It is aimed to make this review a source for future studies in this aspect. This study was performed in 3 different approaches, in first approach possible partial replacement by glass waste was studied, in second, partial replacement by plastic waste was studied and in third, replacement by both glass and plastic waste together was studied. Selective targeting of mechanical characteristics such as compressive strength, flexural strength, split tensile strength, modulus of elasticity was done in the article as they are the most important aspects which need to be considered.

- KEY WORDS : Glass powder, Polyethylene terephthalate, Compressive strength, Waste utilization

- HOW TO CITE THIS PAPER : Kumar, Rohit and Jain, Ritesh (2020). Reusing waste materials in concrete. Internat. J. Agric. Engg., 13(2) : 267-271, DOI: 10.15740/HAS/IJAE/13.2/267-271. Copyright@2020: Hind Agri-Horticultural Society. 